\title{
The Duality of Arab Israeli Identity and the Politics of Survival in Sayed Kashua's Let it Be Morning
}

\author{
Neha Soman ${ }^{1}$, V. Suganya² \& Dr. B. Padmanabhan ${ }^{3}$ \\ ${ }^{1}$ ICSSR Doctoral Fellow, Department of English, Bharathiar University, neha.efl@buc.edu.in' \\ https://orcid.org/0000-0003-3900-36070 \\ ${ }^{2}$ Research Scholar (PhD), Department of English, Bharathiar University, suganya.efl@buc.edu.in, \\ https://orcid.org/0000-0002-0989-2653 \\ ${ }^{3}$ Assistant Professor, Department of English, Bharathiar University, padmanabhan@buc.edu.in, \\ https://orcid.org/0000-0001-7395-126X
}

\begin{abstract}
This essay closely reads the Arab Israeli author Sayed Kashua's Let It Be Morning to construe the complex survival trajectories of Arab minority in Israel's plural society. Kashua discusses the relentless struggles of Arab Israelis, caught in-between their social identification with Israeli citizenship and Palestinian nationalism. The novel captures the subjective and collective consequences of Israel's ethnic democracy on Arab community and demonstrates the social patterns in which Arab Israelis perceive, experience, and respond to systematic social segregation. This essay, through its interpretation of Arab Israeli experiences manifested in the novel explores the conflict of contested minority identities through the Saidian discourse of the orientalism and Anderson's imagined communities. The nature of intra-communal rivalry among the minority groups for survival is also of interest to this study as the narrative locates the behavioural changes observed within the Arab community due to the negative environmental circumstances. The study also posits the sociological aspects of reinforcement theories to construe human behaviour in politically challenged environments.
\end{abstract}

Keywords: Israel, Arabs, Communal living, Reinforcement, Survival, Behaviour, Coexistence

Textual interpretation of auto-fictive narrations is incomplete without exploring authors' subjective history intertwined with the societal realms of the stories. The notion of contextualising the author (Aurell, 2015, p.244) is significant to this study as it aims to construe a collective crisis through the author's personal prism of life experiences. Sayed Kashua is Israel's one of the most prominent writers of Hebrew language. Born in Tira, an Arab village in Israel, Kashua has experienced the notion of duality where his innate Arab identity and Israeli citizenship disorder the idea of "belonging" (Kashua, 2014). Kashua's portrayal of Israel's cultural and ethnic complexity is realistic and honest similar to his contemporaries like Ayman Sikseck (b. 1984) who belongs to the new generation Arab Israeli writers of Hebrew language (Shimony, 2013). As a bilingual writer, 
Kashua's choice of Hebrew as the linguistic modality is as complex as the implications of Hebrew for Israel's ethnic varieties. Professor Reuven Snir addresses the complexity of bilingual writers who are anxious about the intense split elicited from the politicisation of Hebrew though bilingualism is ordinary in Israeli society. Snir states, "on the one hand you don't want to lose yourself, on the other hand you do want to fit in" (1998 as cited in Shimony, 2013, p.148). But Kashua's approach here is that of resistance. His desire to fit into Israeli society as depicted in his debut fiction Dancing Arabs was unapologetically objected. Kashua posits a form of literary confrontation against the social and civil unjust in the language of his oppressor by sharing his experience of being an Arab Israeli in Hebrew language. Kashua's narratives explore the fragmented society of Israel and expose the lives of ethnic minorities caught in between uncertainty and fear. His unusual humor and self-irony reflect the sense of helplessness experienced especially by Arab Israeli in the current of mainstream politics and terrorism.

Let it be Morning (2006), translated from Hebrew by Miriam Shlesinger conjures the images of being an Arab Israeli and portrays their tenacious struggles to survive in a social environment under inhumane conditions. The unnamed narrator of the novel who is also the protagonist is an Israeli journalist forced to abandon his dreams in the city. He returns to his village in Tira when his identity as an Arab subjects him to extreme discriminations. Though humiliated and in despair, the narrator imagines a pleasant and peaceful return to his village as he would not be interrogated for his identity. However, falsifying his believes; the village turns to be a malicious community of self-absorbed individuals which reflects the surreal uncertainty of life. The situation in the village is further worsened as an unanticipated state-imposed siege disorients the village turning it into a darwinian jungle. Kashua traces the collapse of human values as the villagers are exposed to life threatening circumstances. The climax of the novel is painstakingly vivid as the narrator's village is transferred to the Palestinian authority in exchange for a few Jewish settlements in the West Bank. Though there are mixed reactions over the new Palestinian identification of the village, the narrator address the transfer to be brutal as their lives are exposed to more threat, discomfort and adversity. The ruthless exploitation of Israeli Arabs can be construed through the Saidian concept of orientalism. Said (1979) states,

Orientalism is not a mere political subject matter or field that is reflected passively by culture, scholarship, or institutions; ... It is rather a distribution of geopolitical awareness into aesthetic, scholarly, economic, sociological, historical, and philological texts ... it is, above all, a discourse, that is by no means in direct, corresponding relationship with political power in the raw, but rather is produced and even exists in an uneven exchange with various kinds of power...

Kashua's narrative as an aesthetic text share geopolitical awareness of Jewish/Arab conflict in Israel. The narrator's experiences in the city as an Arab, his imposed return and the final territorial exchange deliberate the hegemonic power associated with a geographical space. Said in The Question of Palestine (1992) argues that the Arabs have been considered oriental throughout history. Their lives are treated "less human and valuable than Europeans and Zionists" (p.28) therefore, unapologetically mistreated. He also laments that the whole world legitimised the creation of a Jewish state and ignored what the Jewish enterprise "meant in loss, dispersion, and catastrophe" (p.xiii) for the Palestinian people. The oriental status of Arabs in Israeli society 
bewilders Kashua. Similar to the Saidian discourse of the oriental, Kashua says that he was never considered as a citizen of Israel. The separatist policies of the State dismantle social order and target the Arab minorities in particular. The desire to be a part of the society is vivid in his words but was always treated as an outsider. The helplessness of the author reflects through the Arab characters of the novel who fall victim to the contentious politics of the State. The autobiographic undertones of the text exemplify Kashua's subjective expression of criticism of Israeli society. The protagonist of the novel is not a splendid hero, but a common man disillusioned by the events that occurs around him. He is shattered when his return to the homeland turns out to be a nightmare. When the Israeli military surrounds his village blocking all the amenities, he witnesses his own people turning hysteric for survival. The village transforms into a Darwinian jungle where survival of the fittest alone is assured.

"That's one of the things I wanted to escape from Israel-not being considered as a citizen...That the 'be thankful despite your position' is such a humiliating issue when it comes to minorities. 'Be thankful' 'you can't compare yourself'...It...was so painful for someone who thought he was a citizen." (Kashua, 2017)

Similar to Kashua's subjective experiences, the novel's narrator also had to endure the wrath of Jewish community when terrorists from the occupied territories attacked Jewish people in Israeli cities. His life in the city transforms into a dreadful experience when his identity as an Israeli Arab is ridiculed, hated and mistrusted. The newspaper firm gradually suspends him off his duties though he held a reputed position as he could fearlessly report stories from the Palestinian villages. He is instructed to disengage from the proceedings of the newspaper as the political tension between Israel and the Palestinian authority intensifies. The government and Jewish community suspected Arab Israelis for helping the terrorists to attack Israel. The narrator faces the heat of hostility as he is explicitly discriminated by his Jewish coworkers. Every single word written by the narrator was scrutinised and censored under the conception that he would manipulate the stories for the benefits of his community. The narrator's desperate attempts to prove his innocence and allegiance to Israel were blatantly rejected; rather they demeaned his actions and mistrusted his intentions.

"I said thank you every time someone told me that "Israeli Arabs really ought to thank you." I agreed with my roommates when they criticized the Arab leadership in Israel, I denounced the Islamic Movement when they did, I expressed my grief over every Jewish casualty after a terrorist attack, I felt guilty, I cursed the suicide bombers, I called them cold-blooded murderers. I cursed the God, the virgins, Paradise and myself. Especially myself, for doing everything I could to hold on to my job." (Kashua, 2006, p. 21)

The narrator's futile attempts for acceptance in Jewish society are to be sympathised as he willingly denounces Palestinian terrorism and comforts his coworkers with his compliant behaviour. He meant to empathise with Jewish loss and tolerated their hostility. He swore against the Islamic Movement that attacks Jewish people. He lived in fear of losing the city of his dreams and his job. Israeli Professor Sammy Smooha (2000) argues that Israeli Arabs are "resigned to their fate as Israeli citizens and see their future in Israel, hoping that a solution to their plight will be found within the framework of the state of Israel and not by disconnecting from it" (p.170). He 
adds that Israeli Arabs, even today, "have high Israeli standards and aspirations" (p.170). Smooha's observations are reflected in narrator's behaviour. He yearns for acceptance and recognition in Israeli society. He did not wish to return to his village, because as Smooha argued, he kept aspirations for a better future in Israel. However, the narrator's aspirations were destroyed as he was subjected to extreme discrimination. He was emotionally robbed to the extent that he made the decision to leave the city for his village.

But I decided I'd had enough. Somehow I came to the conclusion that it would be much safer to live in an Arab village. Somehow it seemed to me that if I lived in a place where everyone was like me, things would be easier. I'd watch them get married and have children, and I'd feel more comfortable. I needed to return to a place, however small it might be, where Arabs didn't have to hide. Especially since so many people were returning anyhow. Very few were leaving, and apart from those who'd been banned, everyone would come back sooner or later. (Kashua, 2006, p. 21)

The narrator's decision to return was undoubtedly compulsive. He could no longer stay in the city as he was subjected to merciless humiliation. Jewish people were turning furious against Israeli Arabs. Surprisingly, the narrator's wife wanted to stay back in spite of the severe waves of hostility and discrimination. "She didn't show any signs of concern when someone sprayed the wall of our building with ARABS OUT = PEACE + SECURITY. More than anything, she hated the village ... she just used to say, "You don't know the people there. You don't know what it's turned into" (Kashua, 2006, p. 17). She condemned his decision as she feared that their village might have changed and they will not be accepted there. She preferred to live in the city no matter how indifferent they were treated. She constantly warned her husband that he had "no idea what people there can do to anyone who isn't one of them" (Kashua, 2006, p.18). Her thoughts are extremely ironical as she is willing to lead an oppressed life among Jewish people but she is frightened to return to her village and live with her own community. On the other hand, the narrator felt hopeful at the thought of relocating to their village. He imagined a pleasant and comforting life among his people where his family will not be judged or mistreated. The memories of Tira offered him peace. The mixed emotions manifested here represent the illusion of nationalism which can be read through the discourse of Benedict Anderson who defines nation as an imagined political community. Anderson (2006) says, "it is imagined because the members of even the smallest nation will never know most of their fellow-members, meet them, or even hear of them, yet in the minds of each lives the image of their communion." (p.6)

Similarly, the narrator feels connected with the people of his village even if he is away from them. His estrangement offers a sense "a conception of personhood, identity . . which must be narrated" (Anderson, 2006, p.204). Narrator's nationalistic awakening is a social construction meant to identify himself the people of his community. Despite his wife's discontent, the narrator's family relocates to Tira in the hope for a peaceful life but seldom did they expect an unfortunate fate. The narrator at first is perplexed towards the eccentric behaviour of his people but gradually realises the latent causes behind their shocking transformation. The behavioural changes undergone by the villagers as a collective is interpreted within the theoretical framework of reinforcement theory. 
American social philosopher and psychologist B.F.Skinner noted in his book Beyond Freedom and Dignity (1971) that there should be fundamental changes in human behaviour which cannot be achieved only with the help of physics and biology. The science of human behaviour was approached by Skinner through what can be called as behaviourism or reinforcement theory (Van Wagner, 2010). Reinforcement is a powerful stimulus which influences the way human beings behave (Petri, 1981). It propounds the notion that social behaviour is influenced, controlled and governed by external events outside the human psyche. Stimuli are external events which play a significant role in the theory of social reinforcement. The stimuli can be any event which can lead to a change in human behavioural patterns and this change is referred to as the response. The fundamental premise of the theory is that human beings are more likely to engage in a specific behaviour if it is followed by the occurrence of something pleasant or appealing. The theory also puts forth the possibility of an opposite premise which states that people are less likely perform a specific behaviour if the following occurrence is negative or unpleasant. The implications of reinforcement can be applied to the social situation narrated in the novel to synthesise human behaviour in challenging environments. For instance, the narrator at his arrival feels confused towards the eccentric behaviour of the villagers. He feels unfamiliar and unacquainted.

I hate myself for thinking that coming back to the village would solve anything. For some reason, I thought that if I was surrounded by people like myself, my own people, nothing bad could happen to me. I thought that in the village I'd be much more sheltered than I was in the Jewish neighborhood. I thought the village would make a good guesthouse for me to come back to at the end of my working day, like everyone else. (Kashua, 2006, 170171)

The narrator was unable to comprehend the reason behind this change. Tira was his final resort. He dreamt of returning to the village to spend his life peacefully among his people. He believed that his family would be accepted by the villagers; after all, he was an Arab and his identity was supposed to unite them. But to his shock, he was not welcomed in the village. The villagers no more were pleasant people who lived in harmony. They were exhausted, furious and treated each other with suspicion. The narrator discerns that the villagers are physically and psychologically weakened due to their exclusion from the mainstream. They were even deprived off basic rights as Israeli citizens and were forced to live in secluded communities in the frontiers. Chandra (2006) states,"ethnic identities are a subset of identity categories in which eligibility for membership is determined by attributes associated with, or believed to be associated with, descent (described here simply as descent-based attributes." (p. 398)

The narrator expected the recognition of his ethnic group to acquire respect, peace and coexistence which were rejected to him in the Jewish city. However, he confronted hostility and regretted his decision. Skinner argues that the subjective drives of human beings can be manipulated because they exhibit certain behavioural patterns based on the impact of its result on them. He was concerned about human behavior and his environment in which he is living (Winokur, 1971) and argued that a positive and valued consequence can lead to the behaviour being repeated and a negative or undesirable consequence can be withheld to strengthen the probability of the behaviour being repeated. But what affected the behavioural change of the villagers were the absence of positive reinforcement, reversal of negative reinforcement and the 
occurrence of punishment and extinction. The narrator's memories of the village were pleasant and hopeful but the reality was depressing. "Actually, I hardly recognize the place ... but for some reason I don't really feel like I'm going back to an old familiar place. I'm going home, to a new place." (Kashua, 2006, p. 16)

He felt trapped in a strange place. He could not comprehend the reason behind the distressing behaviour of the villagers. But slowly the narrator solves this mystery. His daily life in the village makes him realise that his village is exposed to wretched and life-threatening circumstances under law which clearly discriminates and oppresses Arab communities. The narrator understands that life in the village is more challenging than it is in the city. The villagers are mistreated and there are no signs of improvement in their miserable living conditions. The depressing environment has altered the behavioural pattern of the villagers which is reflected in their attitude towards the narrator. The innate desire for recognition and appreciation cannot be omitted when human behaviour is discussed. Every individual, despite their age and gender will exhibit an invincible desire to be rewarded for their social actions. American psychologist Charles Catania acknowledges constant presence of rewards (reinforces) in the society. He argues that the reinforcers are already there, and they should not be wasted (Catania, 2000, p.23-37). But in this case, the villagers were not only rejected from identifying reinforces in their community, but they were also demotivated and excluded from the State as a collective.

The Israeli Arabs", I can hear someone say after the commercial, "never felt part of the State of Israel. They're really Palestinians, whose relatives live on the West Bank and in Gaza. The transfer of lands to the Palestinian Authority has spared Israel the enormous danger of a rising Islamic Movement and other nationalist movements from within.... They've always complained about being discriminated against and about their minority status, and we should be pleased that our democracy will finally have real meaning. (Kashua, 2006, p. 269)

Reinforces need not necessarily be concrete entities; rather they can even be affirmative signs of approval which would result in a pleasant behaviour. The positive consequences of a behaviour exhibited substantiate the significance of continuing a particular behavioural pattern which is appealing and acceptable to everyone. Thus, a mutual reinforcement society in which reinforces are delivered reciprocally is likely to be a happy society (Skinner, 2008). This was clearly not the case of narrator's village. They were punished for the crimes of others and were blatantly rejected from the societal mainstream. The brutal rejection had shattered their hopes for better lives. The torments which were enforced upon the villagers transfigured them into emotionless beings who shared meaningless existence. It was the absence of moral support and acceptance that had distressed the village and forced the people to derive an unappealing behavioural pattern.

The reinforcement theory identifies the possibility of negative reinforcement in which a positive or appealing behaviour is maintained by the removal of aversive stimuli. Negative reinforcement "plays a central role in the development of many behaviors, appropriate as well as inappropriate. .." (Iwata, 1987, p.362). It observes human nature to produce affirmative social actions when they are situated in a positive environment. Thus, the absence of undesirable or 
harmful events may increase the probability of exhibiting and maintaining positive behavioural patterns. But what might happen if the negative reinforcement is reversed? How would people react when they are surrounded by aversive events? This aspect of reinforcement is examined to interpret the behavioural changes of the villagers. Narrative evidences can be discerned from the novel. The lives of the villagers were severed from freedom on personal and collective levels. They were forcefully conditioned as submissive to the regime. However, the systematic exploitation had severely affected the behaviour of the villagers.

If I'm in the line at the grocery shop and someone cuts in front of me, I should just stay cool. He swears that people have been killed in recent years because of things like that. Slowly his laughter dies down. "You have no idea what you're coming back to, do you?" he says, and his tone changes. (Kashua, 2006, p. 30)

The people of the village were expected to control their urge to react as they were severely punished if deviated from the expected behaviour. Ashraf, a friend of the narrator explains how they should behave in public considering the probable consequences of their actions. He states that people were killed for insignificant reasons and nobody had the courage to interrogate such brutal behaviours and he warns the narrator to consider his safety and not to rebel against what has been happening in the village. Ashraf reminds the narrator that the village is no longer the same and he should be careful enough not to cause any problem which might turn fatal. Thus the behavioural change of the villagers can be justified considering the possible consequences of their social actions. Their ability to demonstrate meaningful behaviour was interrupted by its negative consequences, causing physical and psychological harm to the people and as the result of which, they demonstrate detrimental behaviours. Life in the village was undoubtedly under threat."We'll always have wars in this godforsaken place. Take any six feet in this place and you'll find too much damage, too much turmoil, too much chaos in every part of our lives, which means that wars will never end." (Kashua, 2006, p. 74)

The narrator understands that the unnatural behaviour of the villagers was caused by the negation of positive atmosphere and the persistence of aversive stimuli. As their social lives were constantly disturbed by unfavorable interventions, they reciprocated the same emotions, which in turn portrayed them as unacceptable and intolerable individuals. The reinforcement theory propounds two interconnected occurrences which observe the causes for negative or undesirable behaviour. While negative reinforcement focuses on removing aversive events to evoke a desirable behaviour, punishment imposes negative consequences to discourage unwanted behaviour. Though punishment in reinforcement theory is one way to control undesired behaviour (Sidman and Boren, 1957; Shnidman, 1968) it can also inflict fear (Gershoff et al., 2010) and cause aggressive behaviours (Gershoff, 2002). In the novel, the villagers were not expected to demand their rights because it was considered as an unwanted behaviour that the dominant group wished to suppress. Thus, they imposed punishments in the form of negative stimuli which had led to the extinction of the natural behaviour of the people. On the other hand, extinction is an attempt made to extinguish a particular behaviour by withholding positive reinforcement. But what happened with the people of the village was the enforcement of both these phenomena. The probability of positive reinforcements was negated and negative consequences were constantly imposed upon them which further complicated their lives and made it meaningless. 
In the theory of natural selection, the unfit species become extinct in organic nature, letting only the fittest species to survive and prosper. The English philosopher and biologist Herbert Spencer invented the term "survival of the fittest" in his Principles of Biology as a synonym for Darwin's natural selection. "This survival of the fittest, which I have here sought to express in mechanical terms, is that which Mr. Darwin has called 'natural selection' or the preservation of favoured races in the struggle for life" (Spencer, 1864, p. 444). Spencer's ideas about natural selection were greatly influenced by his political standpoints. He argued that the government interventions should be limited as it might disturb the natural and unrestricted progress of the society. He repudiated the equal distribution of opportunities to people despite their capacity to respond to them. This belief had led him to oppose all the aids given to the weaker sections of the society whom he thought to be unfit and therefore, should be eliminated. He observed the state interventions to improve the lives of the poor as "artificial preservation of those least able to take care of themselves" (Hofstadter, 1965, p.41) and stated that "the whole effort of Nature is to get rid of such, to clear the world of them, and make room for better" (p.41). Darwin has also explained the callous fight observed in nature for survival where the stronger dominates the weaker for progress. English economist Thomas Malthus propagates the conception of fight or competition between human beings in a community for resources required for their survival. The term Malthusian Catastrophe is coined to justify the positive checks in nature such as famine, disease and war that have kept the population from increasing quickly (Ospovat, 1999). Darwin has applied Malthusian understanding of survival to the whole of nature, and suggested that the fight for survival would be won by the strongest and the fittest. Darwin extended his claim from the animal world of the jungle by comprising human beings and social thought. He also emphasised the fact that the struggle for survival is an inevitable law of nature.

In Let it be Morning, Kashua's literary genius captures the transformation of a community into a darwinian jungle when it is checked (in the Malthusian Catastrophe) by the possibility of a war. Regardless of their ethnic association, people fight against each other to survive and exist. The Israeli army surrounded the village and blocked their roads. The siege had also blocked further supply of food and water to the village and the villagers were forced to sustain with limited resources as they were uncertain about the future. The unpleasing circumstances created tension among the villagers and gradually separated them from one another by inflicting in them the fear of extinction.

I'm thrilled. I knew it. People just didn't think about the fact that they'd be needing water and sodas too, and there are a few bottles left. I take as many as I can carry and ask the shop owner to add them to my bill. Bottles of Coke, orange juice and the mineral water that hardly anybody buys unless it's for infants, on doctor's orders. My brother sees me approaching the car and gives a big smile. I signal him to go inside and get some more, and stuff everything into the trunk. (Kashua, 2006, p. 175)

Even the narrator, who had blamed the villagers for their indifferent behaviour, was terrified to expect a catastrophe. He realised that village would run short of food and water due to the siege. Before others could understand the urgency of the situation, he began to store as much resources as possible. The narrator's actions appear as a contradiction to his previous selfportrayal. He was once judgmental towards the people of the village and hated them for their 
unnatural social performances. But he was also transformed into a self-absorbed individual when the question of survival was raised. He had prior awareness about the expected catastrophe but did not warn the villagers to be prepared. Rather, he ensured the safety of his family by purchasing all the necessary items from the shops. Though his actions were morally corrupt as he did not show any consent for his fellow beings, he is justified as per the law of natural selection. He realised that the fit only would survive, therefore, competed against his own community to ensure his existence. Similarly, the entire village delved into a darwinian jungle fighting to survive a political catastrophe.

\section{Funding Disclosure}

Neha Soman acknowledges the financial support rendered by Indian Council of Social Science Research (ICSSR) by the award of Centrally Administered Full-Term Doctoral Fellowship. [File No. RFD/2019-20/GEN/CULT/149]

\section{References}

Anderson, B. (2006). Imagined communities: reflections on the origin and spread of nationalism. Verso.

Aurell, J. (2015). Making history by contextualizing oneself: Autobiography as historiographical intervention. History and Theory, 54(2), 244-268. https://doi.org/10.1111/hith.10756

Catania, A. C. (2000). Ten points every behavior analyst needs to remember about reinforcement. In J. C. Leslie \& D. Blackman (Eds.), Experimental and applied analyses of human behavior (pp. 23-37). essay, Context Press.

Chandra, K. (2006). What is Ethnic Identity and Does it Matter? Annual Review of Political Science, 9(1), 397-424. https://doi.org/10.1146/annurev.polisci.9.062404.170715

Gershoff, E. T. (2002). Corporal punishment by parents and associated child behaviors and experiences: A meta-analytic and theoretical review. Psychological Bulletin, 128(4), 539-579.

https://doi.org/10.1037/0033-2909.128.4.539

Gershoff, E. T., Grogan-Kaylor, A., Lansford, J. E., Chang, L., Zelli, A., Deater-Deckard, K., \& Dodge, K. A. (2010). Parent Discipline Practices in an International Sample: Associations With Child Behaviors and Moderation by Perceived Normativeness. Child Development, 81(2), 487-502.

https://doi.org/10.1111/j.1467-8624.2009.01409.x

Hofstadter, R. (1965). Social Darwinism in American thought. Beacon Press.

Iwata, B. A. (1987). Negative Reinforcement in Applied Behavior Analysis: An Emerging Technology. Journal of Applied Behavior Analysis, 20(4), 361-378. https://doi.org/10.1901/jaba.1987.20-361

Kashua, S. (2006). Let it be morning. (M. Shlesinger, Trans.). Black Cat.

Kashua, S. (2014, July 4). Why Sayed Kashua is leaving Jerusalem and never coming back. Haaretz.com. https://www.haaretz.com/.premium-for-sayed-kashua-co-existence-has-failed-1.5254338.

Monahan, I. (2017, September 28). A Conversation With Sayed Kashua on Arab-Israeli Identity. Moment Magazine. https://momentmag.com/conversation-sayed-kashua-arab-israeli-identity/. 
Ospovat, D. (1999). The development of Darwin's theory: natural history, natural theology, and natural selection, 1838-1859. Cambridge University Press.

Petri, H. L. (1981). Motivation: Theory. Reaserch, and Applications (4th ed.). Cole publishing Company.

Said, E. W. (1979). Orientalism. Vintage Books.

Said, E. W. (1992). The question of Palestine. Vintage.

Shimony, B. (2013). Shaping Israeli-Arab Identity in Hebrew Words-The Case of Sayed Kashua. Israe/ Studies, 18(1), 146. https://doi.org/10.2979/israelstudies.18.1.146

Shnidman, S. R. (1968). Extinction of Sidman Avoidance Behavior. Journal of the Experimental Analysis of Behavior, 11(2), 153-156. https://doi.org/10.1901/jeab.1968.11-153

Sidman, M., \& Boren, J. J. (1957). The relative aversiveness of warning signal and shock in an avoidance situation. The Journal of Abnormal and Social Psychology, 55(3), 339-344. https://doi.org/10.1037/h0043237

Skinner, B. F. (1971). Beyond freedom and dignity. Bantam Books.

Skinner, B. F. (2008). Walden two. Hackett Publ.

Smooha, S. (1978). Israel: Pluralism and conflict. University of California Press.

Smooha, S. (2000). Ethnic Democracy: Israel as a Prototype. In R. Gavison \& D. Hacker (Eds.), The JewishArab Rift in Israel: A Reader (pp. 168-172). essay, Arab Society in Israel.

Smooha, S. (2019). Institutional separation. Arabs and Jews in Israel, 88-93. https://doi.org/10.4324/9780429037863-8

Spencer, H. (1864). The principles of Biology. Williams and Norgate.

Van Wagner, K. (2010). B. F. Skinner biography (1904-1990). Psychology. http://psychology.about.com/od/profilesofmajorthinkers/p/bio_skinner.htm.

Winokur, S. (1971). Skinner's Theory of Behavior An Examination of B. F. Skinner's Contingencies of Reinforcement: A Theoretical Analysis. Journal of the Experimental Analysis of Behavior, 15(2), 253259. https://doi.org/10.1901/jeab.1971.15-253

Neha Soman is an ICSSR doctoral fellow of English at Bharathiar University, India. Her research in Middle Eastern Studies engages with the interplay of memory, place-identity and race in the notion of coexistence in war-torn nation states. She is also an active blogger at Word Press.

Suganya Vijayabaskaran is a doctoral scholar of English at Bharathiar University, India. Her research is entitled "Narratives of Memory, Trauma, and Resilience: Contextualising the Facets of Historical Revisionism and Identity Reconstruction in the Select Contemporary Irish Novels".

Dr B Padmanabhan is an Assistant Professor of English at Bharathiar University, India, where he teaches Cognitive Literary Studies, Contemporary Critical Theory, Indian Aesthetics, and other courses. His research interests include Ethnic and Area Studies, Memory Studies, and Digital Humanities 